DOI: $10.21802 / \mathrm{artm} .2021 .4 .20 .65$

UDC 616-071.3:616.155.32:616.98-092.19-008.64(477.83)

\title{
ANTHROPOMETRIC PROFILE OF PATIENTS LIVING WITH HIV/AIDS IN LVIV REGION
}

\author{
A.Ya. Orfin ${ }^{1,2}$, M.A. Mazepa ${ }^{1}$ \\ ${ }^{1}$ Lviv State University of Physical Culture named after Ivan Bobersky, Department of physical therapy and \\ occupational therapy, Lviv, Ukraine, \\ ORCID ID: 0000-0002-5374-1246, e-mail:aorf87@gmail.com, \\ ORCID ID:0000-0002-2199-4791, e-mail:mrmazepa@ukr.net; \\ 2"Lviv Regional Infectious Diseases Clinical Hospital", Lviv, Ukraine
}

\begin{abstract}
The body of PLHIV undergoes profound anthropometric changes in adipose tissue distribution, which develop under the influence of pathogenetic mechanisms caused by HIV and due to impaired side effects of ART. ART leads to the development of lipoatrophy / lipohypertrophy syndrome. This phenomenon is described as a syndrome characterized by the loss and/or accumulation of fat and has three types: lipohypertrophy, lipoatrophy, and mixed lipodystrophy. These changes in body shape are very important to determine because they are associated with negative disease dynamics and high mortality. Therefore, it is extremely important to detect this syndrome early to ensure a better quality of life for this population, as the clinical approach is not easy. Potential approaches to treatment, including lifestyle changes, with adequate eating habits, exercise, and some medical interventions, showed little effect in PLHIV. In this case can be effectively reduced through exercise. Despite the existence of established exercise guidelines, the effective dosage of exercise to reduce HRT requires verification.
\end{abstract}

The aim. Study the anthropometric parameters in PLHIV and establish the relationship between the parameters and the degree of viral load (HV) of HIV, the level of CD4 + T-lymphocytes.

Materials and methods: 60 patients aged 18 to 60 years were examined. We used standard methods of measuring the following anthropometric indicators: body weight, height, chest circumference, waist and hips. The waist-tothigh ratio index was also determined. The calculation of the body mass index was performed according to the standard formula by dividing body weight (in kilograms) by the square of height (in square meters). The indicator 18.5-24.9 is considered normal. The level of CD4 + T-lymphocytes was determined by flow cytofluorometry. The viral load of HIV was determined by real-time PCR. Statistical indicators, median, Pearson's coefficient, Student's t-test, were calculated using Microsoft Excel 2016.

Results. The average waist circumference was smaller in both the men of the experimental group $(74.5 \pm 10.3$ $\mathrm{cm})$ and the women of the experimental group $(61.9 \pm 11.0 \mathrm{~cm})$ than in the control groups of men $(90.4 \pm 9.4 \mathrm{~cm})$ and women $(67.5 \pm 7.3 \mathrm{~cm}(\mathrm{p}<0.05))$. The average ratio of waist circumference to hip circumference in the group of male PLHIV was $0.94 \pm 0.08 \mathrm{~cm}$ in the control group of men $-0.97 \pm 0.8 \mathrm{~cm}(\mathrm{p}<0.05)$. In the group of female PLHIV, this indicator reached $0.86 \pm 0.1 \mathrm{~cm}$, and in the control group - $0.75 \pm 0.3 \mathrm{~cm}(\mathrm{p}<0.05)$. The mean forearm circumference was lower in the two research groups. However, in men with HIV $(18.5 \pm 3.1 \mathrm{~cm})$ this figure was lower than in women with HIV $(19.9 \pm 3.9 \mathrm{~cm}(\mathrm{p}<0.05))$. Also, the circumference of the tibia was larger in female PLHIV $(26.9 \pm 3.9 \mathrm{~cm})$ than in male PLHIV $(20.8 \pm 3.8 \mathrm{~cm}(\mathrm{p}<0.05))$.

Conclusions. PLHIV at the stage of AIDS leads to the recomposition of the body. It is manifested by a decrease in BMI, waist circumference, hip, mid-upper arm, and calf, which indicates lipodystrophy. Increase in the index of the waist circumference to hip circumference ratio indicates a probable redistribution of adipose tissue. BMI cannot be used as an accurate method to determine obesity or lipodystrophy. A positive correlation was found between the value of the anthropometric profile and the level of viral load and CD4 + T-lymphocytes. Early administration of ART and dosed exercise is likely to have a positive effect on the body structure of PLHIV in the AIDS stage, although this requires further research.

Keywords: AIDS, HIV, anthropometric profile, CD4+ T-lymphocytes.

Introduction. The body of PLHIV undergoes profound anthropometric changes, primarily due to the changes in adipose tissue distribution, which develop under the influence of pathogenetic mechanisms caused by HIV (low-intensity inflammation, oxidative stress, mitochondrial dysfunction, profound metabolic disorders) and due to impaired side effects of ART [1,2]. ART leads to the development of lipoatrophy / lipohypertrophy syndrome and associated risks of the pathology of the cardiovascular system [3]. This phenomenon is described as a syndrome characterized by the loss and/or accumulation of fat and has three types: lipohypertrophy (accumulation of fat in the anterior abdominal wall), lipoatrophy (reduction of fat on the periphery of the body mainly in the face and lower extremities), and mixed lipodystrophy (association of lipoatrophy with lipohypertrophy) [2]. These changes in body shape are very important to determine because they are associated with negative disease dynamics and high mortality [4]. In addition, the subjective feeling of the change in the body image in PLHIV deepens the negative self-esteem and leads to a decrease in quality of life [5]. Therefore, it is extremely important to detect this 
syndrome early to ensure a better quality of life for this population, as the clinical approach is not easy. Several trials attempted to find a way to treat these body changes, but so far, no single solution was found. Potential approaches to treatment, including lifestyle changes, with adequate eating habits, exercise, and some medical interventions, showed little effect in PLHIV [7,8].

It is also known from the literature that visceral adipose tissue (VAT) is harmful fat deposits in the human body that can be effectively reduced through exercise [9]. Despite the existence of established exercise guidelines, the effective dosage of exercise to reduce HRT requires verification.

Justification of the research. Among the nondrug interventions that could affect the improvement of anthropometric changes in the body of PLHIV, in addition to a balanced diet and individually selected diet, the positive effect of therapeutic exercises is expected [10]. The analysis of randomized controlled trials (RCTs) found in 9 databases showed that only high-intensity interval training and aerobic exercise of moderate intensity were useful for reducing body fat accumulation [11].

Anthropometric indicators can be used as markers of the effectiveness of therapeutic exercises, so before developing an individual rehabilitation program, it is advisable to conduct a detailed study of the main indicators of the structure of the body of PLHIV. Thus, the problem of changes in the anthropometric profile and its correction in PLHIV remains relevant.

The aim: to study anthropometric parameters in patients with PLHIV at the stage of HIV/AIDS and to establish a relationship with the degree of viral load (HV) of HIV, the level of CD4 + T-lymphocytes.

Materials and methods. Achieve the objective, we examined 60 patients treated at the Lviv Regional Infectious Diseases Clinical Hospital. Criteria for inclusion in the study were the written voluntary informed consent, the absence of severe comorbidities, mental and cognitive disorders, age from 18 to 60 years. The exclusion criteria were: children and adolescents, pregnancy, nursing mothers with HIV-positive status, and refusal to participate in the research.

The research was performed in compliance with the basic provisions of the Ethical Principles and Guidelines for Research Involving Human Subjects approved by the Declaration of Helsinki (1964-2013), ICH GCP (1996), EEC Directive № 609 (from 24.11.1986), orders of the Ministry of Health of Ukraine № 690 dated 23.09.2009, № 944 dated 14.12.2009, № 616 dated 03.08.2012.

Socio-demographic data was obtained by analyzing the records in medical cards.

We used standard methods of measuring the following anthropometric indicators: body weight, height, waist and hip circumference, legs, forearms. The index of the ratio of waist circumference to hip circumference was also determined. The calculation of body mass index was performed with the standard formula: body weight (in kilograms) divided by the square of height (in square meters). The indicator 18.5-24.9 is considered normal. Cardiovascular risk and abdominal obesity were determined by calculating the ratio of waist/hip circumference to waist circumference.

The level of CD4 + T-lymphocytes was determined by flow cytofluorometry. The viral load of HIV was determined by real-time PCR.

Statistical indicators, median, Pearson's coefficient, and Student's t-test were calculated using Microsoft Excel 2016.

Results. Patients were divided into two research groups based on gender: group I included 20 women, group II - 40 men. Descriptive data for both groups is displayed in Table 1. The mean age of patients in group I was $39 \pm 7.5$ years, group II $-39 \pm 7.7$ years. At the time of selection for the research, the majority of patients from group I and group II were married: 30 (75\%) and 14 (70\%), respectively. In group I, $25(63 \%)$ patients lived in urban areas, and in group II - $12(60 \%)$ patients. The vast majority of HIV patients had higher education.

During the collection of data on patients, it was found that in the male group, the number of employed participants was lower (16 (40\%)) than the unemployed (24 $(60 \%)$ ). Among female PLHIV, 4 (20\%) were unemployed and $16(80 \%)$ were employed. Among PLHIV, 10\% were involved in heavy manual labor such as construction or mine work. The control group included 50 relatively healthy residents of the Lviv region. Their age range was 19 - 50 years, with the average age of women $34 \pm 4.7$ years and men $-41 \pm 4.2$ years.

Socio-demographic characteristics of patients

\begin{tabular}{|c|c|c|c|c|c|}
\hline \multicolumn{2}{|c|}{ Characteristic } & $\begin{array}{c}\text { Group I, } \\
\mathrm{n}=40 \\
(\text { men) }\end{array}$ & $\begin{array}{l}\text { Control group } \\
\mathrm{n}=30 \text { (men) }\end{array}$ & $\begin{array}{c}\text { Group II } \\
n=20 \\
\text { (women) }\end{array}$ & $\begin{array}{c}\text { Control group } \\
n=30 \\
\text { (women) }\end{array}$ \\
\hline \multicolumn{2}{|c|}{ Age } & $39 \pm 7,5$ & $41 \pm 4,2$ & $39 \pm 7,7$ & $34 \pm 3,5$ \\
\hline \multirow[t]{2}{*}{ Education } & Secondary & $12(30 \%)$ & 10 & $8(40 \%)$ & 7 \\
\hline & Higher & $28(70 \%)$ & 20 & $12(60 \%)$ & 23 \\
\hline \multirow{3}{*}{$\begin{array}{l}\text { Marital } \\
\text { status }\end{array}$} & Married & $30(75 \%)$ & 16 & $14(70 \%)$ & 18 \\
\hline & Unmarried & $8(20 \%)$ & 14 & $3(15 \%)$ & 12 \\
\hline & Widow / widower & $2(5 \%)$ & 0 & $3(15 \%)$ & 0 \\
\hline \multirow[t]{2}{*}{ Employment } & Employed & $16(40 \%)$ & 25 & $16(80 \%)$ & 26 \\
\hline & Unemployed & $24(60 \%)$ & 5 & $4(20 \%)$ & 4 \\
\hline \multirow{2}{*}{$\begin{array}{c}\text { Place of resi- } \\
\text { dence }\end{array}$} & Urban & $25(63 \%)$ & 22 & $12(60 \%)$ & 17 \\
\hline & Rural & $15(37 \%)$ & 8 & $8(40 \%)$ & 13 \\
\hline
\end{tabular}


Clinical and laboratory characteristics of HIV/AIDS are presented in Table 2. The main route of HIV transmission was sexual (heterosexual and unprotected promiscuous sexual behavior) in $74 \%$ of patients enrolled in the research. The average level of CD4 + T-lymphocytes in both experimental groups was below 200 cells / ml: in group I the number of CD4 + T-lymphocytes was $138.2 \pm 101.6$ cells $/ \mathrm{ml}$, and in group II $-141.5 \pm 136.7$ cells / $\mathrm{ml}(\mathrm{p} \leq 0.05)$. Thus, according to the HIV classification, $100 \%$ of PLHIV had an irreversible condition known as AIDS.

Among male PLHIV, $43 \%$ received ART, and the mean duration of ART was $2.6 \pm 0.8$ years. In the female PLHIV group, more participants received ART - 70\%, and the duration of specific therapy was $2.9 \pm 0.3$ years.

The viral load was high in both groups: women $443693.2 \pm 446814$ copies / ml, men - $311209.7 \pm$ 241191.7 copies / $\mathrm{ml}$.

Table 2

Clinical and laboratory characteristics of the patients

\begin{tabular}{|c|c|c|c|}
\hline \multicolumn{2}{|l|}{ Sign } & Group I, n = 40 (men) & Group II, $\mathrm{n}=20$ (women) \\
\hline \multirow[t]{2}{*}{ ART } & Received & $17(43 \%)$ & $14(70 \%)$ \\
\hline & did not received & $23(57 \%)$ & $6(30 \%)$ \\
\hline \multicolumn{2}{|c|}{ The average duration of ART } & $2.6 \pm 0.8$ years & $2.9 \pm 0.3$ years \\
\hline \multirow{2}{*}{\multicolumn{2}{|c|}{$\begin{array}{l}\text { Stage of the disease } \\
\text { Live with HIV }\end{array}$}} & $40(100 \%)$ & $20(100 \%)$ \\
\hline & & $9,4 \pm 1,7$ years & $8,9 \pm 0,7$ years \\
\hline \multicolumn{2}{|c|}{$\begin{array}{l}\text { The average level of CD } 4+ \\
\text { T-lymphocytes }\end{array}$} & $138,2 \pm 101,6$ cells $/ \mathrm{ml}$ & $141,5 \pm 136,7$ cells $/ \mathrm{ml}$ \\
\hline \multicolumn{2}{|c|}{ HIV viral load } & $311209,7 \pm 241191,7$ copies $/ \mathrm{ml}$ & $443693,2 \pm 446814$ copies $/ \mathrm{ml}$ \\
\hline
\end{tabular}

Table 3 shows the results of anthropometric measurements performed in the experimental and control groups. It should be noted that non-genetically determined indicators, namely BMI and contours of the waist, hips, forearms, legs were lower in the research groups than in controls. The average height of PLHIV (genetically determined) in the first experimental group was $180.0 \pm 0.04$ $\mathrm{cm}$, in the second experimental group $164 \pm 0.05 \mathrm{~cm}$, and in the first and second control groups $-182 \pm 0,9 \mathrm{~cm}$ and $165 \pm 0.09$ respectively $(\mathrm{p} \leq 0.05)$. The mean body weight of HIV-infected men was higher $(64.7 \pm 10.1 \mathrm{~kg})$ than that of $\mathrm{HIV}$-infected women $(50.7 \pm 7.03 \mathrm{~kg}),(\mathrm{p} \leq 0.05)$.
However, the mean body weight in both experimental groups was lower than in both control groups, namely in healthy men $79.4 \pm 8.3 \mathrm{~kg}$ and in healthy women $65.3 \pm$ $2.6 \mathrm{~kg}(\mathrm{p} \leq 0.05)$.

The average BMI in the first experimental group was $20.02 \pm 3.1 \mathrm{~kg} / \mathrm{m} 2$, which was lower than in the control group - $23.6 \pm 1.7 \mathrm{~kg} / \mathrm{m} 2$. In the female PLHIV group, the mean BMI was significantly lower than in the control group $-19.01 \pm 2.6 \mathrm{~kg} / \mathrm{m} 2$ and $23.1 \pm 1.9 \mathrm{~kg} / \mathrm{m} 2$, respectively. No statistically significant differences were found between the comparison groups $(\mathrm{p} \leq 0.05)$.

Anthropometric indicators of the studied patients

\begin{tabular}{|c|c|c|c|c|c|c|c|c|c|c|}
\hline & \multicolumn{2}{|c|}{$\begin{array}{c}\text { Men } \\
\mathrm{n}=40\end{array}$} & \multicolumn{2}{|c|}{$\begin{array}{c}\text { Control } \\
\text { (men) } n=30\end{array}$} & \multirow[t]{2}{*}{$\mathrm{p}$} & \multicolumn{2}{|c|}{$\begin{array}{c}\text { Women } \\
\mathrm{n}=20\end{array}$} & \multicolumn{2}{|c|}{$\begin{array}{c}\text { Control } \\
\text { (women) } \mathrm{n}=30\end{array}$} & \multirow[t]{2}{*}{$\mathrm{p}$} \\
\hline & $\begin{array}{l}\text { Mean } \pm \\
\text { SD }\end{array}$ & Range & $\begin{array}{l}\text { Mean } \\
\pm \mathrm{SD}\end{array}$ & Range & & $\begin{array}{c}\text { Mean } \pm \\
\text { SD }\end{array}$ & Range & $\begin{array}{c}\text { Mean } \pm \\
\text { SD }\end{array}$ & Range & \\
\hline Height (cm) & $\begin{array}{c}180,0 \pm \\
0,04\end{array}$ & $172-191$ & $\begin{array}{c}182 \pm \\
0,9\end{array}$ & $72-191$ & p 0,02 & $164 \pm 0,05$ & $\begin{array}{c}154- \\
172\end{array}$ & $165 \pm 0,09$ & $\begin{array}{c}156- \\
177\end{array}$ & $\mathrm{p} 0,03$ \\
\hline Weight (kg) & $\begin{array}{c}64,7 \pm \\
10,1 \\
\end{array}$ & $41-94$ & $\begin{array}{c}79,4 \pm \\
8,3 \\
\end{array}$ & $\begin{array}{c}65,1- \\
98,4 \\
\end{array}$ & p 0,04 & $\begin{array}{c}50,7 \pm \\
7,03 \\
\end{array}$ & $38-72$ & $65,3 \pm 2,6$ & $59-72$ & p 0,05 \\
\hline BMI (kg/m2) & $\begin{array}{c}20,02 \pm \\
3,1 \\
\end{array}$ & $\begin{array}{c}13,5- \\
28,5\end{array}$ & $\begin{array}{c}23,6 \pm \\
1,7 \\
\end{array}$ & $\begin{array}{c}20,1- \\
24,7 \\
\end{array}$ & p 0,03 & $\begin{array}{c}19,01 \pm \\
2,6 \\
\end{array}$ & $\begin{array}{l}14,5- \\
25,5\end{array}$ & $23,1 \pm 1,9$ & $\begin{array}{c}19,8- \\
24,4 \\
\end{array}$ & p 0,02 \\
\hline $\begin{array}{l}\text { Waist circum- } \\
\text { ference }(\mathrm{cm})\end{array}$ & $\begin{array}{c}74,5 \pm \\
10,3\end{array}$ & $\begin{array}{l}52,3- \\
100,5\end{array}$ & $\begin{array}{c}90,4 \pm \\
9,4\end{array}$ & $\begin{array}{l}84,5- \\
101,2\end{array}$ & p 0,05 & $\begin{array}{c}61,9 \pm \\
11,0\end{array}$ & $\begin{array}{l}440,1- \\
79,2\end{array}$ & $67,5 \pm 7,3$ & $\begin{array}{c}58,2- \\
76,1\end{array}$ & p 0,03 \\
\hline $\begin{array}{l}\text { Hip circum- } \\
\text { ference }(\mathrm{cm})\end{array}$ & $\begin{array}{c}79,3 \pm \\
7,6\end{array}$ & $\begin{array}{c}65,3- \\
98,6\end{array}$ & $\begin{array}{c}92,4 \pm \\
8,7\end{array}$ & $\begin{array}{l}89,2- \\
110,3\end{array}$ & p 0,03 & $\begin{array}{c}71,7 \pm \\
10,3\end{array}$ & $\begin{array}{l}47,7- \\
85,4\end{array}$ & $93,8 \pm 4,2$ & $\begin{array}{c}77,8- \\
99,7\end{array}$ & p 0,04 \\
\hline $\begin{array}{l}\text { Waist-hip ra- } \\
\text { tio }(\mathrm{cm})\end{array}$ & $\begin{array}{c}0,94 \pm \\
0,08\end{array}$ & $\begin{array}{c}0,78- \\
1,12\end{array}$ & $\begin{array}{c}0,97 \pm \\
0,8\end{array}$ & $0,8-1,0$ & p 0,05 & $0,86 \pm 0,1$ & $\begin{array}{c}0,66- \\
1,05\end{array}$ & $0,75 \pm 0,3$ & $\begin{array}{c}0,7- \\
0,9\end{array}$ & p 0,05 \\
\hline $\begin{array}{l}\text { Mid-upper } \\
\text { arm circum- } \\
\text { ference meas- } \\
\text { ure }(\mathrm{cm})\end{array}$ & $\begin{array}{c}18,5 \pm \\
3,1\end{array}$ & $\begin{array}{l}14,0- \\
24,5\end{array}$ & $\begin{array}{c}28,7 \pm \\
2,4\end{array}$ & $\begin{array}{l}25,2- \\
29,7\end{array}$ & p 0,01 & $19,9 \pm 3,9$ & $\begin{array}{l}13,5- \\
27,3\end{array}$ & $26,4 \pm 3,1$ & $\begin{array}{l}23,7- \\
28,5\end{array}$ & p 0,02 \\
\hline $\begin{array}{l}\text { Calf circum- } \\
\text { ference }(\mathrm{cm})\end{array}$ & $\begin{array}{c}20,8 \pm \\
3,8 \\
\end{array}$ & $6,3-30,1$ & $\begin{array}{c}31,2 \pm \\
2,9 \\
\end{array}$ & $\begin{array}{c}24,5- \\
33,8\end{array}$ & p 0,02 & $26,9 \pm 3,9$ & $\begin{array}{l}20,5- \\
34,1 \\
\end{array}$ & $33,5 \pm 2,7$ & $\begin{array}{c}28,9- \\
35,3\end{array}$ & p 0,04 \\
\hline
\end{tabular}

The average waist circumference was smaller in both men in the experimental group $(74.5 \pm 10.3) \mathrm{cm}$ and women in the experimental group $(61.9 \pm 11.0 \mathrm{~cm})$ than in the control groups of men $(90.4 \pm 9.4 \mathrm{~cm})$ and women $(67$,
$5 \pm 7.3 \mathrm{~cm}(\mathrm{p} \leq 0.05))$. The average ratio of waist circumference to hip circumference in the male PLHIV group was $0.94 \pm 0.08 \mathrm{~cm}$ compared to the male control group with $0.97 \pm 0.8 \mathrm{~cm}$. In the female PLHIV group, the ratio 
reached $0.86 \pm 0.1 \mathrm{~cm}$, and in the control group $-0.75 \pm$ $0.3 \mathrm{~cm}(\mathrm{p} \leq 0.05)$. The mean mid-upper arm circumference measure was smaller in the two research groups. However, in men with HIV $(18.5 \pm 3.1 \mathrm{~cm})$ this figure was lower than in women with HIV $(19.9 \pm 3.9 \mathrm{~cm}(\mathrm{p} \leq 0.05))$. Also, the calf circumference was larger in female PLHIV 26.9 \pm 3.9 $\mathrm{cm}$ than in male PLHIV $20.8 \pm 3.8 \mathrm{~cm}$. However, these figures were lower than in the control groups. No statistical difference was found between the groups $(\mathrm{p} \leq 0.05)$.
The correlation between the indicators studied in the male PLHIV group is shown in Table 4. There was a positive direct correlation between CD4 + T lymphocytes and body weight, BMI, waist circumference, waist / hip circumference index (ITI), mid-upper arm circumference measure, and negative direct correlation with hip circumference.

The viral load had a direct negative correlation with body weight, BMI, waist, hip, mid-upper arm circumference measure, and calf circumference.

Table 4

The correlation between CD4 + T-lymphocyte levels, viral load (VL), height, body weight, BMI, waist circumference (WC), hip (HC), mid-upper arm (MUAC), calf (CC), and WHR in male PLHIV

\begin{tabular}{|l|l|l|l|l|l|l|l|l|}
\hline Characteristic & Height & $\begin{array}{c}\text { Body } \\
\text { weight }\end{array}$ & \multicolumn{1}{|c|}{ BMI } & WC & HC & WHR & MUAC & CC \\
\hline T-lymphocyte & $\mathrm{r}=0,004$ & $\mathrm{r}=0,16$ & $\mathrm{r}=0,19$ & $\mathrm{r}=0,04$ & $\mathrm{r}=-0,1$ & $\mathrm{r}=0,17$ & $\mathrm{r}=0,11$ & $\mathrm{r}=0,11$ \\
levels & $\mathrm{p}=0.0001$ & $\mathrm{p}=0.002$ & $\mathrm{p}=0.02$ & $\mathrm{p}=0.002$ & $\mathrm{p}=0.002$ & $\mathrm{p}=0.0008$ & $\mathrm{p}=0.0002$ & $\mathrm{p}=0.0001$ \\
\hline VL & $\mathrm{r}=0,16$ & $\mathrm{r}=-0,01$ & $\mathrm{r}=-0,02$ & $\mathrm{r}=-0,12$ & $\mathrm{r}=-0,1$ & $\mathrm{r}=0,13$ & $\mathrm{r}=-0,13$ & $\mathrm{r}=0,01$ \\
& $\mathrm{p}=0.03$ & $\mathrm{p}=0.001$ & $\mathrm{p}=0.0001$ & $\mathrm{p}=0.03$ & $\mathrm{p}=0.02$ & $\mathrm{p}=0.0001$ & $\mathrm{p}=0.06$ & $\mathrm{p}=0.002$ \\
\hline
\end{tabular}

Among the women with HIV-positive status, all the indicators, except for the index of the waist to hip circumference ratio, had a direct positive correlation with the level of CD4 + T-lymphocytes. However, the level of viral load was negatively related to the body weight, BMI, waist, hip, mid-upper arm, and calf circumference but had a positive correlation with the waist to thigh ratio. The summary data is shown in Table 5.

Table 5

The correlation between CD4 + T-lymphocyte levels, viral load (VL), height, body weight, BMI, waist circumference (WC), hip (HC), mid-upper arm (MUAC), calf (CC), and WHR in female PLHIV

\begin{tabular}{|l|c|c|c|c|c|c|c|c|}
\hline $\begin{array}{l}\text { Characteris- } \\
\text { tics }\end{array}$ & Height & $\begin{array}{c}\text { Body } \\
\text { weight }\end{array}$ & BMI & WC & HC & WHR & MUAC & CC \\
\hline CD4 + T-lym- & $\mathrm{r}=-0,18$ & $\mathrm{r}=0,4$ & $\mathrm{r}=0,52$ & $\mathrm{r}=0,54$ & $\mathrm{r}=0,5$ & $\mathrm{r}=0,2$ & $\mathrm{r}=0,38$ & $\mathrm{r}=0,35$ \\
phocyte levels & $\mathrm{p}=0,001$ & $\mathrm{p}=0,0003$ & $\mathrm{p}=0,02$ & $\mathrm{p}=0,0001$ & $\mathrm{p}=0,0002$ & $\mathrm{p}=0,03$ & $\mathrm{p}=0,002$ & $\mathrm{p}=0,001$ \\
\hline VL & $\mathrm{r}=0,08$ & $\mathrm{r}=-0,25$ & $\mathrm{r}=-0,3$ & $\mathrm{r}=-0,44$ & $\mathrm{r}=-0,55$ & $\mathrm{r}=0,1$ & $\mathrm{r}=-0,4$ & $\mathrm{r}=-0,41$ \\
& $\mathrm{p}=0,002$ & $\mathrm{p}=0,001$ & $\mathrm{p}=0,02$ & $\mathrm{p}=0,004$ & $\mathrm{p}=0,003$ & $\mathrm{p}=0,0001$ & $\mathrm{p}=0,002$ & $\mathrm{p}=0,003$ \\
\hline
\end{tabular}

Discussion. This research is dedicated to determining the anthropometric profiles of PLHIV at the stage of AIDS. The evidence that waist circumference, waist-toheight ratio, and waist to hip ratio are independent predictors of cardiac risk and metabolic syndrome and are, therefore, important for HIV / AIDS patients receiving antiretroviral therapy, dictated the choice of anthropometric parameters. [12].

The average age of the patients included in the research was $39 \pm 7$ years, according to the report of the Public Health Center of Ukraine. $78.7 \%$ of HIV-infected people in Ukraine are between 29 and 49 years old [13]. Our research showed that the main route of infection was sexual transmission. These results are consistent with the data from the Central Committee of Ukraine ( $71 \%$ heterosexual and $3 \%$ homosexual) and data from researchers in Canada and India (87.4\% heterosexual and $1.3 \%$ homosexual) $[1,13,14]$. In our research, we determined the anthropometric profile and its relationship with the levels of viral load and CD4 + T-lymphocytes in the HIV-infected patients at the AIDS stage. We found that all the anthropometric measurements are positively and significantly correlated with the amount of $\mathrm{CD} 4(\mathrm{P}<0.05)$, which coincides with the results of other researchers $[1,15]$.
In most researches, participants were HIV-positive, however, in stable remission and with $\mathrm{CD} 4+\mathrm{T}$ cell levels of 400 cells/ml and above [11,14,15]. Our research focused on PLHIV at the stage of AIDS with low levels of CD4 + T-lymphocytes $(138.2 \pm 101.6$ cells $/ \mathrm{ml}$ in men and $141.5 \pm 136.7$ cells $/ \mathrm{ml}$ in women $)$.

The mean BMI in our research was $20.02 \pm 3.1$ in men and $19.01 \pm 2.6$ in women. Similar results were demonstrated by the researchers from France - 22.1 [16]. However, a significantly higher BMI (40.2) was demonstrated in a study conducted in Australia [17]. The researched patients at the stage of AIDS had smaller waist circumferences (men 74.5 \pm 10.3 , women 61.9 \pm 11.0 ), hip (men 79.3 \pm 7.6 , women 71.7 \pm 10.3 ), mid-upper arm (men $18.5 \pm 3.1$, women $19.9 \pm 3.9$ ) calf (men $20.8 \pm 3.8$, women $26.9 \pm 3.9)$ compared to the group of people with HIV negative status $[18,19]$. Such changes can be explained by abnormal redistribution of adipose tissue: accumulation of fat in the anterior abdominal wall, [18, 20, 21] increase in dorsocervical fat masses [9,22], loss of fat on arms and legs, face and buttocks [23,24]. Because belly fat is a longterm side effect of ART, we expected to get higher waist circumference values. Our results can be explained by the fact that some PLHIV did not receive ART, or the duration of admission was 6 months or less. The researchers 
studying adipose tissue distribution obtained the following results: the prevalence of lipoatrophy / lipohypertrophy syndrome was $33 \%$ among women and $59 \%$ among men. [3]. In contrast, low contour rates in our research may indicate a probable protein-energy deficiency among PLHIV, which may be associated with low levels of work capacity and high unemployment among the researched patients. We found that the index of the waist circumference to hip circumference ratio in the HIV-positive men was $0.94 \pm 0.08$, which does not differ from the control group. In female PLHIV, this figure was higher $(0.86 \pm$ $0.1)$ than in the control group, which coincides with data from other researches [25, 26]. The researchers explain this phenomenon by the redistribution of fat caused by the long-term use of ART, namely the increase in adipose tissue in the abdomen and thighs [27,28].

Conclusions. Based on the findings, we can conclude that PLHIV at the stage of AIDS leads to the recomposition of the body. It is manifested by a decrease in BMI, waist circumference, hip, mid-upper arm, and calf, which indicates lipodystrophy. However, an increase in the index of the waist circumference to hip circumference ratio indicates a probable redistribution of adipose tissue, with a predominant accumulation in the abdomen and hips. Thus, despite the decrease in BMI, we see an increase in the index of the waist circumference to hip circumference ratio. Therefore, BMI cannot be used as an accurate method to determine obesity or lipodystrophy in PLHIV at the AIDS stage. A positive correlation was found between the value of the anthropometric profile and the level of viral load and CD4 + T-lymphocytes. Therefore, early administration of ART and dosed exercise is likely to have a positive effect on the body structure of PLHIV in the AIDS stage, although this requires further research.

\section{References:}

1. Deepika A, Seema P. Anthropometric and Nutritional Profile of People Living with HIV and AIDS in India: an Assessment Indian J Community Med. 2014; Jul, 39(3):161-8. DOI: 10.4103/0970-0218.137153.

2. Sacilotto LB, Pereira PCM, Manechini JPV, Papini SJ. Body Composition and Metabolic Syndrome Components on Lipodystrophy Different Subtypes Associated with HIV. J Nutr Metab. 2017; Apr, 2017:8260867. DOI: 10.1155/2017/8260867.

3. Soares LR, Silva DC, Gonsalez CR, Batista FG, Fonseca LAM, Duarte AJS, et al. Discordance between body mass index and anthropometric measurements among HIV-1-infected patients on antiretroviral therapy and with lipoatrophy/lipohypertrophy syndrome. Rev. Inst. Med. Trop. Sao Paulo, 2015; March, 57(2):105-10. DOI: 10.1590/S003646652015000200002.

4. Alves MD, Brites C, Sprinz E. HIV-associated lipodystrophy: a review from a Brazilian perspective. Ther Clin Risk Manag. 2014; Jul, 10:559-566. DOI: 10.2147/TCRM.S35075.

5. Chițu-Tișu CE, Barbu EC, Lazăr M, et al. Body composition in $\mathrm{HIV}$-infected patients receiving highly active antiretroviral therapy. Acta Clin Belg. 2017; Oct, 72(1):55-62. DOI: 10.1080/17843286. 2016.1240426.
6. Dimala CA, Ngu RC, Kadia BM, Tianyi F-L, Choukem SP. Markers of adiposity in HIV/ AIDS patients: Agreement between waist circumference, waist-to-hip ratio, waist-to-height ratio and body mass index. PLoS ONE. 2018; March, 13(3):e0194653. DOI: https://doi.org/10.1371/journal.pone.0194653.

7. Aurpibul L, Namwongprom S, Sudjaritruk T, Ounjaijean S. Metabolic syndrome, biochemical markers, and body composition in youth living with perinatal HIV infection on antiretroviral treatment. PLoS ONE, 2020; March, 15(3):e0230707. DOI: https://doi.org/10.1371/journal.pone.0230707.

8. Jankowski CM, Mawhinney S, Wilson MP, et al. Body Composition Changes in Response to Moderate- or High-Intensity Exercise Among Older Adults With or Without HIV Infection. J Acquir Immune Defic Syndr. 2020; Nov, 85(3):340-345. doi:10.1097/QAI. 0000000000002443.

9. Koethe JR, Lagathu C, Lake JE, et al. HIV and antiretroviral therapy-related fat alterations [published correction appears in Nat Rev Dis Primers. 2020; Jul, 6(1):48. DOI: 10.1038/s41572-020-0181-1.

10. McClunan K, Nel DG, Dhansay MA, van Niekerk E. Effect of Nutritional Intake on the Body Composition of HIV-Exposed and HIV-Unexposed Preterm and Low Birth Weight Infants. Breastfeed Med. 2019; Apr, 14(3):144-153. DOI: 10.1089/bfm.2018.0113.

11. Chang YH, Yang HY, Shun SC. Effect of exercise intervention dosage on reducing visceral adipose tissue: a systematic review and network meta-analysis of randomized controlled trials. Int $\mathrm{J}$ Obes (Lond). 2021; Feb, 45(5):982-997. DOI: 10.1038/s41366-02100767-9.

12. Cheng H, Sewda A, Marquez-Luna C, et al. Genetic architecture of cardiometabolic risks in people living with HIV. BMC Med. 2021; May, 19(1):114. DOI: 10.1186/s12916-020-01762-z.

13. Kuzin I, Martzynovska V, Antonenko Z. State Institution "Public health center of the ministry of health of Ukraine". HIV Infection in Ukraine, Newsletter. Kyiv. 2020; 51:109. https://phc.org.ua/ sites/default/files/users/user90/HIV_in_UA_51_2020 EN.pdf.

14. O'Brien KK, Tynan AM, Nixon SA, Glazier RH. Effectiveness of Progressive Resistive Exercise (PRE) in the context of HIV: systematic review and metaanalysis using the Cochrane Collaboration protocol. BMC infectious diseases. 2017; Apr, 17(1):268. DOI: https://doi.org/10.1186/s12879-017-2342-8.

15. Gogokhia L, Taur Y, Juluru K, Yagan N, Zhu YS, Pamer E, et al. Intestinal Dysbiosis and Markers of Systemic Inflammation in Viscerally and Generally Obese Persons Living With HIV. J Acquir Immune Defic Syndr. 2020; Jan, 83(1):81-89. DOI: 10.1097/QAI.0000000000002229.

16. Goupil de Bouillé J, Vigouroux C, Plessis L, et al. Factors associated with being overweight and obesity in people living with HIV on antiretroviral therapy: socio-clinical, inflammation, and metabolic markers. J Infect Dis. 2021. DOI: 10.1093/infdis/jiab151.

17. Petoumenos K, Kuwanda L, Ryom L, Mocroft A, Reiss $\mathrm{P}$, De Wit S, et al. Effect of Changes in Body Mass Index on the Risk of Cardiovascular Disease and 
Diabetes Mellitus in HIV-Positive Individuals: Results From the D:A:D Study. J Acquir Immune Defic Syndr. 2021; Apr, 15; 86(5):579-586. DOI: 10.1097/QAI.0000000000002603. PMID: 33351531.

18. Dos Santos AP, Navarro AM, Schwingel A, Alves TC, Abdalla PP, Venturini ACR, et al. Lipodystrophy diagnosis in people living with HIV/AIDS: prediction and validation of sex-specific anthropometric models. BMC Public Health. 2018; Jun, 27; 18(1):806. DOI: 10.1186/s12889-018-5707-z.

19. Fouché C, van Niekerk E, du Plessis LM. Anthropometric Parameters of HIV-Infected and HIVUninfected Mothers and their Premature Infants. J Trop Pediatr. 2018; Aug, 1; 64(4):255-261. DOI: 10.1093/tropej/fmx056.

20. Strijdom H, De Boever P, Walzl G, Essop MF, Nawrot TS, Webster I, et al. Cardiovascular risk and endothelial function in people living with HIV/AIDS: design of the multi-site, longitudinal EndoAfrica study in the Western Cape Province of South Africa. BMC Infect Dis. 2017; Jan, 7; 17(1):41. DOI: 10.1186/s12879-016-2158-y.

21. Raposo MA, Armiliato GNA, Guimarães NS, Caram CA, Silveira RDS, Tupinambás U. Metabolic disorders and cardiovascular risk in people living with HIV/AIDS without the use of antiretroviral therapy. Rev Soc Bras Med Trop. 2017; Sep-Oct, 50(5):598606. DOI: 10.1590/0037-8682-0258-2017.

22. Alencastro PR, Barcellos NT, Wolff FH, Ikeda ML, Schuelter-Trevisol F, Brandão AB, et al. People living with HIV on ART have accurate perception of lipodystrophy signs: a cross-sectional study. BMC Res Notes. 2017; Jan, 10(1):40. DOI: 10.1186/s13104-0172377-3.

23. Gabriel, CL, Ye, F, Fan R, Nair S, Terry, JG, Carr JJ, et al. Hepatic Steatosis and Ectopic Fat Are Associated With Differences in Subcutaneous Adipose Tissue Gene Expression in People With HIV. Hepatol Commun. 2021; Feb. DOI: https://doi.org/10.1002/hep4.1695

24. de Oliveira T, Kharsany AB, Gräf $\mathrm{T}$, et al. Transmission networks and risk of HIV infection in KwaZulu-Natal, South Africa: a community-wide phylogenetic study. Lancet HIV. 2017; Jan, 4(1):4150. DOI: 10.1016/S2352-3018(16)30186-2.

25. Steenkamp L, Truter I, Williams M, Goosen A, Oxley I, van Tonder E, et al. Nutritional status and metabolic risk in HIV-infected university students: challenges in their monitoring and management. South African Family Practice. 2017; 59(1):9-13. DOI: https://doi.org/10.4102/safp.v59i1.4653

26. van Zoest RA, van den Born BH, Reiss P. Hypertension in people living with HIV. Curr Opin HIV AIDS. 2017; Nov, 12(6):513-522. DOI: 10.1097/COH.0000000000000406.

27. Lake JE. The Fat of the Matter: Obesity and Visceral Adiposity in Treated HIV Infection. Curr HIV/AIDS Rep. 2017; Dec, 14(6):211-219. DOI: 10.1007/s11904017-0368-6.

28. Yitbarek GY, Engidaw MT, Ayele BA, Tiruneh SA, Alamir MT. Magnitude of Obesity/Overweight and Its Associated Factors Among HIV/AIDS Patients on
Antiretroviral Therapy in Jimma Zone Hospitals, South West Ethiopia: Hospital-Based Cross-Sectional Study. Diabetes Metab Syndr Obes. 2020; Apr, 13:1251-1258. DOI: 10.2147/DMSO.S247221.

29. Barceló C, Guidi M, Thorball CW, Hammer C, Chaouch A, Scherrer AU, et al. Impact of Genetic and Nongenetic Factors on Body Mass Index and WaistHip Ratio Change in HIV-Infected Individuals Initiating Antiretroviral Therapy. Open Forum Infect Dis. 2020; Jan, 7(1):464. DOI: 10.1093/ofid/ofz464.

УДК 616-071.3:616.155.32:616.98-092.19-

008.64(477.83)

\section{АНТРОПОМЕТРИЧНИЙ ПРОФІЛЬ ПАЦІЕТІВ, ЩО ЖИВУТЬ 3 ВІЛ, НА СТАДЇ̈ СНІДУ У ЛЬВІВСЬКІЙ ОБЛАСТІ}

\author{
А.Я. Орфін ${ }^{1,2}$, М.А. Мазепа ${ }^{1}$
}

${ }^{1}$ Львівський державний університет фізичної культури імені Івана Боберського, кафедра фізичної mepaniï ma epгomepanii,,

м. Львів, Україна,

ORCID ID: 0000-0002-5374-1246,

e-mail:aorf87@gmail.com,

ORCID ID: 0000-0002-2199-4791,

e-mail:mrmazepa@ukr.net;

${ }^{2}$ КНП ЛОР «Львівська обласна інфекиійна клінічна лікарня», м. Львів, Україна

Резюме. Цілі: вивчити антропометричні показники у пацієнтів з ЛЖВ на стадії ВІЛ/СНІДу і встановити зв'язок зі ступенем вірусного навантаження (BН) ВІЛ, рівнем CD4+ Т-лімфоцитів.

Матеріали і методи: обстежено 60 пацієнтів. Виміряно антропометричні показники, рівень CD4+ Tлімфоцитів і вірусне навантаження.

Результати. Середній обвід талії був меншим як у чоловіків дослідної групи 74,5 $\pm 10,3$ см, так і у жінок дослідної групи 61,9 $\pm 11,0$ см, ніж у контрольних групах чоловіків 90,4 \pm 9,4 см та жінок 67,5 \pm 7,3 см ( $>$ < 0.05). Середній показник співвідношення обводу талії до обводу стегон у ЛЖВ чоловічої статі 0,94 $\pm 0,08 \mathrm{~cm}$, а у контрольній групі чоловіків $-0,97 \pm 0,8$ см ( $<$ < 0.05). У ЛЖВ жіночої статі цей показник сягав $0,86 \pm 0,1 \mathrm{~cm}$, а у контрольній групі - 0,75 $\pm 0,3 \mathrm{~cm}(\mathrm{p}<$ 0.05). Середній обвід передпліччя був нижчим у двох дослідних групах. Але у чоловіків з ВІЛ 18,5 $\pm 3,1 \mathrm{~cm}$ він був меншим, ніж у жінок з ВІЛ 19,9 $\pm 3,9$ см (p < $0.05)$. Обвід гомілки був більшим у жінок з ВІЛ $26,9 \pm$ 3,9 см, а у чоловіків з ВІЛ $-20,8 \pm 3,8 \mathrm{~cm}(\mathrm{p}<0.05)$.

Висновки. У ЛЖВ на стадії СНІДу відбувається рекомпозиція тіла. Це проявляється зменшенням IMT, обводів талії, стегон, передпліччя та гомілок. Збільшення індексу співвідношення обводу талії до обводу стегон вказує на ймовірний перерозподіл жиру, 3 переважним накопиченням на животі і стегнах. Також спостерігається збільшення індексу співвідношення обводу талії до обводу стегон. Тому IMT не може використовуватися для точного визначення ожиріння чи ліподистрофії. Виявлено позитивну кореляцію між 
величиною антропометричного профілю та рівнем вірусного навантаження і CD4+ Т-лімфоцитів. Тому раннє призначення АРТ та дозованого фізичного навантаження можуть позитивно впливати на будову тіла ЛЖВ на стадії СНІДу.

Ключові слова: ВІЛ/СНІД, антропометричний профіль, CD4+ Т-лімфоцити.

УДК 616-071.3:616.155.32:616.98-092.19008.64(477.83)

\section{АНТРОПОМЕТРИЧЕСКИЙ ПРОФИЛЬ ПАЦИЕНТОВ, ЖИВУЩИХ С ВИЧ, НА СТАДИИ СПИДа ВО ЛЬВОВСКОЙ ОБЛАСТИ}

\author{
А.Я. Орфин ${ }^{1,2}$, М.А. Мазепа ${ }^{1}$ \\ ${ }^{1}$ Львовский государственный университет \\ физической культуры имени Ивана Боберского, \\ кафедра физической терапии и эрготерапии, \\ г. Львов, Украина, \\ ORCID ID: 0000-0002-5374-1246, \\ e-mail:aorf87@gmail.com, \\ ORCID ID: 0000-0002-2199-4791, \\ e-mail:mrmazepa@ukr.net; \\ ${ }^{2}$ КНП ЛОР «Львовская областная инфекционная \\ клиническая больница», г. Львов, Украина
}

Резюме. Цели: изучить антропометрические показатели у пациентов с ЛЖВ на стадии ВИЧ/СПИДа и установить связь со степенью вирусной нагрузки (BН) ВИЧ, уровнем CD4+ Т-лимфоцитов.

Материалы и методы: обследовано 60 пациентов. Измерено антропометрические показатели, уровня CD4+ Т-лимфоцитов и вирусную нагрузку ВИЧ.

Результаты. Средний обвод талии был меньше как у мужчин опытной группы 74,5 $\pm 10,3$ см, так и у женщин опытной группы $61,9 \pm 11,0$ см, чем в контрольных группах мужчин 90,4 \pm 9,4 см и женщин $67,5 \pm 7,3$ см $(\mathrm{p}<0.05)$. Средний показатель соотношения обводов талии к обводу бедер у ЛЖВ мужского пола $0,94 \pm 0,08 \mathrm{~cm}$, в контрольной группе мужчин $0,97 \pm 0,8$ см $(\mathrm{p}<0.05)$. У ЛЖВ женского пола этот показатель был $0,86 \pm 0,1$ см, а в контрольной группе $0,75 \pm 0,3$ см $(\mathrm{p}<0.05)$. Средний обвод предплечья был ниже в двух опытных группах. Однако у мужчин с ВИЧ $18,5 \pm 3,1$ см он был меньше, чем у женщин с ВИЧ $19,9 \pm 3,9$ см $(\mathrm{p}<0.05)$. Также обвод голени был больше у ЛЖВ женского пола $26,9 \pm 3,9$ см, чем у ЛЖВ мужского пола $20,8 \pm 3,8 \mathrm{~cm}(\mathrm{p}<0.05)$.

Выводы. У ЛЖВ со СПИДом происходит рекомпозиция тела. Она проявляется уменьшением ИМТ, обводов талии, бедер, предплечья и голеней. Увеличение индекса соотношения обводов талии к бедрам указывает на вероятное перераспределение жировой ткани с преимущественным накоплением на животе и бедрах. Несмотря на уменьшение ИМТ, наблюдается увеличение индекса соотношения обвода талии к обводу бедер. Поэтому ИМТ не может использоваться для точного определения ожирения или липодистрофии в ЛЖВ со СПИДом. Выявлена положительная корреляция между величиной антропометрического профиля и уровнем вирусной нагрузки и CD4+ Т-лимфоцитов. Поэтому раннее назначение АРТ и дозированной физической нагрузки могут положительно влиять на телосложение ЛЖВ со СПИДом.

Ключевые слова: ВИЧ/СПИД, антропометрический профиль, CD4+ Т-лимфоциты.

Стаття надійшла в редакцію 12.12.2021 р. Стаття прийнята до друку 20.12.2021 p. 